\title{
CAREFUL SEEING: A VISUAL RESEARCH PROJECT WITH CHILDREN
}

\author{
OLHAR CUIDADOSO: \\ UMA PESQUISA VISUAL COM CRIANÇAS
}

Wendy Luttrell ${ }^{1}$

\begin{abstract}
This paper is based on a longitudinal visual ethnographic project with children growing up in poor and working-class communities in Worcester, Massachusetts, who were given disposable cameras to photograph their family, school, and community lives. The research was interested in considering what role, if any, gender, race, ethnicity, class, and immigrant status would have in how the young people (at ages 10,12,16, and 18) would represent their lives. The focus is on the power of their counter-narratives of care, which questioned the dominant representations imposed on them, and presented care as a social good that is necessary to civic society in a way that cannot be understated.
\end{abstract}

Keywords: Children. Ethnography. Photography. Care.

RESUMO: Este artigo se baseaia em um projeto etnográfico visual longitudinal com crianças de comunidades pobres e da classe trabalhadora em Worcester, Massachusetts, aos quais foram dadas câmeras descartáveis para que fotografassem as vidas de suas famílias, escolas e comunidades. A pesquisa interessava-se por considerar quais eram os possíveis papéis exercidos por gênero, raça, etnia e classe, bem como pelo status de imigrantes, na forma como jovens (de 10, 12, 16 e 18 anos) representavam suas vidas. Foca-se no poder de suas contranarrativas de cuidado, que questionam as representações dominantes a eles impostas e apresentam o cuidado como bem social necessário à sociedade civil de um modo que não pode ser subestimado.

Palavras-chave: Crianças. Etnografia. Fotografia. Cuidado.

1.City University of New York - The Graduate Center -New York (NY), United States of America.

*Corresponding author: wluttrell@gc.cuny.edu

Thematic issue organized by: Gilka Girardello, Adriana Hoffmann and Inês Vitorino Sampaio 


\section{Introduction}

'Imagine you have a cousin your age who is moving to town and coming to your school. Take pictures of your home, school, and community that will help him/her know what to expect.'

The aforementioned prompt for picture-taking set the stage for my work with children in a longitudinal, visual ethnography project, Children Framing Childhoods. The project put cameras in the hands of a diverse group of ten-year-old children, attending a public elementary school in Worcester, Massachusetts, USA. The school, Park Central School (PCS), was a microcosm of the racial, ethnic, and linguistic diversity, as well as the working-class character of Worcester, the second largest city in New England. Alongside an influx of (im)migrant families, the school's student population shifts from year to year, as families move into and around the city in search of work and affordable housing. Ninety-two percent of PCS students are eligible for free and reduced school lunch, which, in colloquial terms, means it serves 'low-income' and 'working-poor' families. According to PCS descriptors, 37 percent of its students are white; 10 percent black; 18 percent Asian; and 35 percent Hispanic. The school does not collect data on immigrant status, but a third of the students speak languages other than English at home.

When this project began, in 2003, I was interested in the role that gender, race, ethnicity, class (relative advantage), and immigrant status would have in how the children represented their lives. I imagined that their images would lead me into their classrooms and into their homes, but what I learned far surpassed my expectations and understandings of 'what matters most' to them (another picture-taking prompt of the project).

I had turned to using photography for several reasons, but especially the mobility and portability of cameras, which offer entry into both the emotional and geographical spaces of children's life-worlds-a chance to see, if only in brief glimpses, through their eyes. Having already learned the power of youth-generated images to convey what may be seeable, but not easily sayable (LUTTRELL 2003), I was anticipating that photography might offer specific insight. Thirty-six children were given disposable cameras (ancient technology now) with 27 exposures and four days to photograph their everyday lives. After hearing the aforementioned initial prompt, the children brainstormed together a set of additional prompts that included the following: 'What do you do after school and on the weekends?'; 'What do you like most?'; 'Where do you feel comfortable?'; 'Who do you admire?'; 'Where do you feel respect?', 'What concerns you?'” After the pictures were developed, either I or a research assistant interviewed each child to talk about their images, why they had taken them, what pictures they wished they had taken, but did not, and which photographs they wanted to show their peers, teachers, and a larger public. Then the children met in small groups of six to discuss each other's photos without adult direction, a strategy which provided a unique window into particular ways the children used their cameras and photographs to make identity claims, and vie for status and dignity. Finally, we met as a whole group to plan and design a public exhibition of their work ${ }^{2}$. This same process was followed at age 12 with the single prompt: 'Take pictures of what matters most.'

My project adapted the 'photo-voice' and 'photo elicitation' practices of many researchers over the previous twenty years (CLARK-IBANEZ, 2004; CLARK, 1999; COOKE; HESSE, 2007; KAPLAN, 2013; LUTTRELL; CHALFEN, 2010; MITCHELL, 2011; ORELLANA, 1999; PROSSER; 
BURKE, 2007; THOMPSON, 2008; TINKLER, 2008; YATES, 2010;). I wanted to extend this practice of 'giving kids cameras research,' and offer a line of more critical and creative analysis. My aim was to simultaneously leverage the kids ${ }^{3}$ knowledge and meaning making, but also to question, if not retrain, 'researcher' and 'educator' (all too often white, Anglo, middle-class, color-evasive) lenses and gazes. While visual research has the promise, the possibility to interrupt or up-end these gazes, it does not necessarily do so.

The main tenets of critical childhood studies grounded the project. Research in critical childhood studies seeks to illuminate the social and institutional forces that constrain children's freedom and imagination, and devalues their intentions, agency, and subjectivities. It also aims to privilege and amplify young people's own perspectives and experiences, treating them as competent social actors in their own right, no matter where they 'fit' into child development discourses (ADLER; ADLER, 1986; AMBERT, 1986; WAKSLER, 1986; ALANEN, 1988; THORNE, 1987, 1993; JAMES; PROUT, 1990; JENKS, 1992; QVORTRUP et al., 1994). Such an approach relies on innovative methods and practices that aim to minimize adults 'voicing over' children's experiences and perspectives, so that young people can be heard in new ways. At the same time, a critical perspective on childhood does not assume a singular or essentialized 'child's' voice or 'eyesight,' and recognizes the contingent meanings of childhood (ARIES, 1962; STEPHENS, 1995), including who counts as a child, when this status begins and ends, and the stark inequality of conditions, treatments, and experiences among different groups of children ${ }^{4}$. As one example, globalization and neoliberal influences in education have recalculated children's identities and value in terms of their performance and productivity, measured by test scores, and shrinking the contours of learning into specific 'skills' and dispositions (DEVINE; LUTTRELL, 2013; SONU; BENSON, 2016). That children's value is assigned conditionally (not inherently) based on their ability to measure up in school, is a discourse that I sought to challenge through this project.

My research stretched the 'giving kids cameras' practice across time and space, inviting the participating kids to take photographs (and later videos) at ages 10,12,16, and 18, as well as to curate and interpret their own and each other's images. The research generated an extensive audio-visual archive: 2,036 photographs; 65 hours of video- and audio-taped individual and small group interviews; voice threads ${ }^{5}$; and 18 video diaries produced by a sub-set of participants from ages 16 to 18 .

I developed a line of analysis aimed to preserve the multiplicity and co-constructed meanings that emerge at the sites of production, image content, and audiencing ${ }^{6}$. I came to call this practice 'collaborative seeing,' making space to both 'see' and 'listen' to the images. 'Collaborative seeing' combines an epistemological stance, methodological protocols, and a creative, arts-based analytic process (FONTAINE; LUTTRELL, 2015; RESTLER; LUTTRELL, 2018; LICO; LUTTRELL, 2011; LUTTRELL, 2010, 2016, 2020; see also http://www.childrenframingchildhoods.com/). 'Collaborative seeing' invites reflexivity and is fueled by the questions: 'Whose way of seeing is this?'; 'In what context?'; 'With what degree of power, authority or control?'; 'Toward what purpose?'; 'And with what consequences?'

As a practice, 'collaborative seeing' appreciates the limits of what adult researchers can know about young people's images, experiences, and life-worlds, and advocates a 'need to know more' stance. 'Collaborative seeing' specifically resists any single orientation to analyzing kids' image making, whether as an aesthetic experience, socio-cultural activity, or cognitive-developmental process, to name three common perspectives (SHARPLES et al., 2003). As an interpretive process, 'collaborative seeing' follows kids' lead and seeks to uncover and focus on the connections they see between their own and each other's images in different contexts and over time, generating both individual and collective 
insights. Through on-going dialogues with and among the kids, researchers, and other viewers (including teachers in teacher development workshops where I have shared the audio-visual archive), the 'collaborative seeing' process draws attention to the contingencies of seeing; that we are positioned to see and be seen in multiple ways through intersectional positions of power, privilege, and status.

Indeed, it is often hard to distinguish between children's own intentions or 'readings' of their photographs and those of the adult researchers who seek to represent them (PIPER; FRANKHAM, 2007). In both cases, a form of 'adultism' (albeit sometimes unwittingly) underlies the practice. There is a nagging and hard-to-answer question when adult researchers give kids cameras: 'What imaginary of childhood and personhood is brought into focus, from whose perspective, and with what purpose in mind?'

I used the tools of 'collaborative seeing' to challenge habitual ways of seeing, or hegemonic visualities-in this case, deficit and damage-based ways of seeing that ignore the resources of poor and working-class kids of color, their families, and communities; blames them for the state of their schools; and often results in excessive attempts to control and punish students (GARCÍA; GUERRA, 2004; VALENCIA, 2010; WEINER, 2003; SHALABY, 2017; TUCK, 2009). In this paper, I consider alternative imaginaries of childhood, specifically the 'child in school' that is brought into focus by the children's images and accounts, and the multiple identities they attempted to convey (TINKLER, 2008).

\section{'She Helps me With Being a Child': Seeing Love Labor}

At age 10, Gabriel took several photographs to express his love and admiration for his mother. He took a photograph of her in the kitchen, lauding her 'creativity with food,' pointing to the cupcakes she had baked and decorated for a bake sale at school. He also described his favorite dish-'White meat that has no bones and also red skin with a lot of pepper. I like hot stuff.' He went on to describe helping his mom in the kitchen: 'I made chicken wings with the stuff that made it tender, I put wine in it and it makes it delicious. I learned that trick from my mom.'

Picking up the photograph, Gabriel caressed its edges and reflected:

That's why I love her very much, because she helps me with a lot of things. She helps me with my homework, and mostly, she helps me with being a child. It is the same mother's rules, clean up your room, fix your bed. But I like it when she does that, it's really nice.

After a pause, he added:

'I love her so much; I could explode from too much.'

Gabriel's mom's 'creativity with food,' her teaching culinary 'tricks,' her help with homework, and her 'rules' are not simply about (re)producing a child in instrumental ways (that is, a child 'ready for school'), but a child who is expressively loving and oriented toward the needs of the other. It is striking that Gabriel sees his mom as helping him with 'being a child' (not 'becoming an adult'), and that he stakes a claim of appreciation for 'the same mother's rules, clean up your room, fix your bed'-spoken as if these are shared or commonly held relations between mother and child. Indeed, as Gabriel would explain about a photograph of his room:

'She helps me so I have to help her to clean up.' 
The multiple audiencings of Gabriel's photographs reveals more about his identity claims. When speaking with the interviewer about a photograph he had taken of his church, Gabriel turned away from the interviewer and gazed directly into the video camera. He held up his photograph and spoke to his mother through the camera: 'Mommy, I took this picture for you, I'm sorry it is blurry.' He then turned back to the interviewer and explained he had taken it because, 'it means so much to her. Later, in conversation with his peers in the small group discussion, Gabriel said he had taken the picture of the church because it is where he goes to 'hang with the older kids', who invite him to join their activities even though he is 'only a fifth-grader.' Similarly, in the discussion about his mom-in-kitchen photograph, Gabriel earned praise from his peers about his mother's cupcakes ('They were gone quick'). Gabriel's eyes gleamed when the children in his small group discussion all agreed that his mom's cupcakes were 'the best', which secured him a valued place in school culture. These multiple audiencings are important, because they highlighted the social worlds children inhabit, worlds in which they seek to establish multiple identities, whether as loving sons, as popular with peers, as valued students whose mothers participate in school culture. This pattern of multiple identities, but particularly of being a 'helpful' 'caring,' and cared for child, could be found across the children's images and accounts.

\section{'That's Not me Now:' Seeing New Identities and Versions of Time}

At age 18, Gabriel (who preferred the pseudonym Juan) ${ }^{7}$ was attending a vocational high school where he was training to become a welder. I had been able to locate 26 of the original 36 kids and invited them to participate in a follow up phase of the research. In this phase, I asked the kids to reflect on their childhood images and talk about how they and their lives had changed. They were also invited to take photographs ('What matters most in your life?') and make video diaries. All the kids agreed to be interviewed about their childhood photographs, although four did not return their consent forms and thus were not interviewed. Of these 22 , eighteen were able and willing to participate in the photography and video portion. I was interested in tracing the kids' own versions of their 'development,' their changes over time, as well as the multiple identities that would be expressed. Again, what I learned exceeded what I anticipated.

Juan chuckled as he looked through his childhood photographs and kept saying, with a slight tone of embarrassment, 'What was I thinking back then? I must have thought I was so cool.' He remembered how he relished the time he spent with the 'older kids' who accepted him at church, and how he wanted to adopt their style. In his words, 'I'm like, "Yo, why do you wear white tees under your shirts and all that?"; "Cause that's gangsta style," they said. I wanted to be like them.'

Gabriel/Juan was unable to participate in the follow-up photography and video component of the project, because he had no time. In addition to his vocational schoolwork, he was working two jobs after school and on the weekends to help his mom pay the bills-as he explained, 'My mom and sister depend on me.' Those who did not participate, like Juan, all gave time constraints as their reason. This dimension of time-its limits and unequal distribution - was an early alert to what would become a central topic across all the participants.

At the end of the interview, I asked Juan whether there was anything else he wanted to say or to ask me:

You made us look good and gave us attention. It was good, and I had some negative qualities, my attitude, 'cause when I got angry, I gave everyone attitude. People talked trash about me, like bad stuff. But you know, times change. That's not me now. 
As I reflect on Juan's, then Gabriel's words and representation of his childhood and multiple identities, I see these are his efforts to 'look good,' not mine. Juan's appreciation for my 'attention' (not only to him, but to 'us'), I believe, is speaking to something quite profound: he is acknowledging the significance of regard, the opportunity to be seen as a subject of value. This regard-this form of care as an opportunity to be seen-is how he represented his mother, as in I 'see you' and 'value you.' Juan/Gabriel's way of seeing was a direct challenge to dominant ways of seeing in schools and in social institutions of social control, which convey the following message: 'I am looking at you; surveilling you; measuring you; sussing you out.' And in the case of wage poor mothers, like those of the young people in this study, there is the prevailing assumption within schools: 'If I don't see you, then you must not care about your child.' Similarly, by the way Gabriel/Juan used his camera to show himself as a 'cared for' child and as a means to establish his belonging and 'goodness' ('people talked trash about me'), he was staking his claim to dignity.

\section{Re-Seeing Care}

The kids in this project used their cameras to make visible the invisible work of care (love labor); to express multiple identities over time; and to demonstrate their own and their families' dignity and 'goodness' (refuting dominant discourses of 'bad,' troubled, or broken). They went to great lengths to represent themselves as a 'caring' and 'cared for' child. They did this in ways that could easily have been misconstrued by adult viewers. Through pictures of their homeplaces (HOOKS, 1990) and cherished belongings, the kids emphasized their sense of self-regard and family ties. They photographed gifts and memorabilia (including family photographs) that linked them to their past, to faraway relatives, and to loved ones both present and absent. Photos like these documented the children's own acts of preservation and display, which are themselves crucial forms of care work: honoring relationships, re-telling histories, and maintaining family ties in the face of significant challenges. In their small group discussions, speaking about these cherished objects were opportunities for the kids to negotiate-and often agree on-the tokens of value that united them. For example, the kids took many photographs of TV screens and video games. The abundance of these images often troubled adult audiences, who saw them through an evaluative lens about the appropriate use of kids' screen time. In speaking about their images of screens, the kids seemed aware of these adult-centered concerns, and found ways to defend against them, including how these photographs served as evidence of being cared for. However, more important than 'having' things (like big-screen TVs, video games, access to cable), was showing that they could participate in peer culture. The kids used their cameras and responded to each other's images as a means to both uphold and reject social differences between themselves and their peers. Indeed, regardless of their personal access to consumer goods, the kids sought to show their knowledge of and expertise, and thus stake claims to their 'belonging' in school (PUGH 2002).

Cherished possessions were signs of care-that they were cared for and that they themselves took care. Other photographs emphasized what I came to call choreographies of care-whether it was photographing their moms, grandmas or aunts in kitchens 'feeding the family ${ }^{8}$, or their own extensive role as caregivers (including routine tasks of cleaning, shopping, laundry, and supervising younger siblings and cousins, as well as taking care of ill or elderly family members and, as teenagers, taking jobs to support the household economy). The kids' spoke about their care work as reciprocal and an important source of self-regard. 
The kids' care consciousness extended to school, as they documented signs of care-from pictures of the school rules (the 5 B's: Be here, be ready, be safe, be respectful, be responsible) to pictures of their 'nice' and 'caring' teachers and principal, and, finally, to their 'learning groups,' where they 'cared' for each other. In the racially complex landscape of their school, it was the kids of color who specifically tied teachers' caring to ethical and moral dimensions of belonging: these kids noted how important it was that teachers listened to them, believed them, and believed in their goodness. These same kids were explicit about their sense of vulnerability, and worried about fighting and violence, communicating uncertainty and anxiety about their safety, as well as a desire to not 'be one of them that gets into a fight,' to not be perceived as a 'bad girl or a 'bad boy.' I heard these contours of care as poignant responses to dominant racialized discourses, in which black and brown children, like Gabriel/Juan, have been systematically denied the 'innocent child' status automatically granted to white children.

The kids' 'counter-narratives of care' (LUTTRELL, 2012, 2013) offer a vision of child and youth development in which care-at home and in school-is presented as multidirectional rather than unidirectional, collaborative rather than competitive, social rather than individual. I argue that embedded in the kids' pictures and accounts is an understanding that care is more than work, more than duty, and more than obligation-though it is all of these things, too. Care is a social good; it is necessary to civic society in a way that cannot be understated.

Preparing a 'caring' child is a dimension of self- and human-ness that has been silenced by neoliberal school policies and accountability culture with its push for performativity, where the 'carefree' and 'productive' child dominates. The kids' ways of picturing care is at odds with school as sites of measurement, standardization, and accountability culture, where students and teachers are turned into 'data' (RESTLER, 2017; VINSON; ROSS, 2003; TAUBMAN, 2009), sidelining the desires of parents, teachers and children themselves to be caring and other-centered. The kids' counter-narratives of care also re-frame the relationship between home and schools as more than a means to promote school success (MOLL et al., 1992), but also as a means to elevate the work and morality of care in a democratic society.

In a society where caregiving is devalued; where class, gender, and racial biases are baked into cultural notions and expectations about who does the work of care; where the work of care is chronically unseen, underpaid, and undervalued; where care work has been relegated to the margins and the shadows (and performed predominantly by [im]migrant women of color); and where care itself has often been curtailed, withdrawn, and rescinded where it is most sorely needed, I suggest that the kids' vision of care is nothing less than revolutionary.

\section{Care-ful Visual Research}

I also want to make the case that seeing with regard, with care, is central to the research process, in this case visual research that is care-ful. Such an approach is grounded in a sustained, 'attentive looking, not staring' at the young people's images, as sociologist Howard Becker would put it. As he writes, do not stare 'and thus stop looking; look actively ... name everything in the picture and write up notes' (BECKER, 1986). He also has strategies for identifying 'the emotions and mood a photograph evokes', encouraging observers to engage in:

[...] a period of fantasy, telling yourself a story about the people and things in the picture. The story needn't be true, it's just a device for externalizing and making clear to yourself the emotion and mood the picture has evoked, both part of its statement (BECKER, 1986). 
Whereas Becker focuses on 'seeing' images, historian Tina Campt writes about ways of 'listening to' images, being attuned to the frequencies of 'affect and impact' that images hold. As she puts it, 'listening to' photographs goes beyond visual scrutiny: 'It is an ensemble of seeing, feeling, being affected, contacted, and moved beyond the distance of sight and observer' (CAMPT, 2017, p. 42).

Such a care-ful approach reminds me of the feminist botanist Barbara McClintock's early writings about her coming to 'know' her plants intimately and the pleasure she drew from that (KELLER, 1982, p. 601). My own immersion in 'knowing' the photographs resonates with McClintock's, and I have struggled to find adequate means to communicate the children's feelings as they were looking at their photographs-the tender way Gabriel had caressed the edges of photograph he had taken of his mother; the sigh in his voice as he spoke of his explosive love for her; as well as my own feelings of looking at his looking.

I cannot argue that I have found the adequate language and the means of visual representation that can communicate these layers of meaning and affect generated and co-constructed by the relationship between the kids, me, and other viewers (http://www.childrenframingchildhoods.com/). This is why I conclude with a provocation and a call to leverage the power of love, care, connection, relationality, and regard in order to change what is valued and what is achieved in research and in the educational enterprise at large.

\section{Notes}

1. See Luttrell (2010) for a full discussion, including how the topic of ethics was covered, as well as issues of consent.

2. The one-on-one interviews were audio and video-recorded, and the group conversations were audio-recorded and then transcribed.

3. I use kids, children and young people interchangeably throughout this paper. Kids was the term used most often by the children at ages 10 to 12 to speak of their age group. Occasionally, they referenced themselves and others in reference to school grade, as 'my brother is a seventh-grader.' At ages 16 to 18, when looking back on their childhood images, they shifted between speaking about 'being a child' or 'when I was a kid', and used a variety of terms to reference their age group, as 'people,' 'kids,' 'teenager,' and, at times, 'high-schoolers.'

4. All of these issues are at the heart of debates over universal 'children's rights' within a context of global inequality.

5. The software program VoiceThread allows users to upload photographs and create audio and text-based commentaries or stories within a secure collaborative network. These digital "voice threads" were created by the kids at ages 16 and 18.

6. See Gillian Rose (2007) for her description of these three sites of meaning making in visual analysis.

7. Gabriel was not the only young person to opt for a new name.

8. I borrowed concepts from M. DeVault's (1991) classic study of women's domestic labor to analyze the multiple meanings that the children attached to their pictures.

\section{REFERENCES}

ADLER, P.; ADLER, P. Introduction. In: ADLER, P.; ADLER, P. (eds.). Sociological Studies of Child Development, 1986, p. 3-9, v. 1. 
ALANEN, L. Rethinking childhood. Acta Sociologica, London, v. 31, n. 1, p. 53-67, 1988. https:// doi.org/10.1177/000169938803100105

AMBERT, A. M. Sociology of sociology: the place of children in North American sociology. In: ADLER, P.; ADLER, P. (eds.). Sociological Studies of Child Development, 1986, p. 11-31, v. 1.

BECKER, H. Doing things differently: selected papers. Evanston: Northwestern University Press, 1986.

CAMPT, T. M. Listening to images. Durham: Duke University Press, 2017.

CLARK, C. D. The autodriven interview: a photographic viewfinder into children's experiences. Visual Sociology, Philadelphia, v. 14, n. 1, p. 39-50, 1999. https://doi.org/10.1080/14725869908583801

CLARK-IBANEZ, M. Framing the social world with photo-elicitation interviews. American Behavioral Scientist, Thousand Oaks, v. 47, n. 12, p. 1507-1527, 2004. https://doi.org/10.1177/0002764204266236

COOKE, T.; HESSE, E. What the camera sees and from whose perspective: fun methodological in engaging children in enlightening adults. Childhood, London, v. 14, n. 1, p. 29-45, 2007. https://doi. org/10.1177/0907568207068562

DEVAULT, M. Feeding the family: the social organization of caring as gendered work. Chicago: University of Chicago Press, 1991.

DEVINE, D.; LUTTRELL, W. Children and value Education in neo-liberal times. Children \& Society, Oxford, v. 27, n. 4, p. 241-244, 2013. (Special Issue: The "valuing" of children in education in neoliberal times - Global perspectives; local practices.) https://doi.org/10.1111/chso.12038

FONTAINE, C.; LUTTRELL, W. Re-centering the role of care in young people's multimodal literacies: a collaborative seeing approach. In: HAMILTON, M. et al (org.). Negotiating spaces for literacy learning: Multimodality and governmentality. London: Bloomsbury Books. 2015, p. 43-56.

GARCÍA, S. B.; GUERRA, P. L. Deconstructing deficit thinking: working with educators to create more equitable learning environments. Education and Urban Society, Beverly Hills, v. 36, n. 2, p. 150-68, 2004. https://doi.org/10.1177/0013124503261322

HOOKS, B. Homeplace (a site of resistance). In: RITCHIE, J.; RONALD, K. (orgs.). Available means: an anthology of women's rhetoric(s). Pittsburgh: University of Pittsburgh Press, 1990, p. 383-390.

JAMES, A.; PROUT, A. Constructing and reconstructing childhood: contemporary issues in the sociological study of childhood. London: Falmer Press, 1990.

JENKS, C. The sociology of childhood: essential readings. Batsford: London and Gregg Revivals, 1992. 
KAPLAN, E. B. 'We live in the shadow:' inner-city kids tell their stories through photographs. Philadelphia: Temple, 2013.

KELLER, E. F. A feeling for the organism: the life and work of Barbara McClintock. New York: W. H. Freeman, 1983.

LICO, S.; LUTTRELL, W. An important part of me: a dialogue about difference. Harvard Educational Review, Cambridge, v. 81, n. 4, p. 667-686, 2011. https://doi.org/10.17763/haer.81.4.j5w3r88703266971

LUTTRELL W. A camera is a big responsibility: a lens for analyzing children's visual voices. Visual Studies, Philadelphia, v. 25, n. 3, p. 224-237, 2010. https://doi.org/10.1080/1472586X.2010.523274

LUTTRELL, W. Making boys' care worlds visible. Boyhood Studies, New York, v. 6, n. 1-2, p. 185201, 2012. https://doi.org/10.3149/thy.0601.186

LUTTRELL, W. Children's counter-narratives of care: towards educational justice. Children \& Society, Oxford, v. 27, n. 4, p. 295-308, 2013. https://doi.org/10.1111/chso.12033

LUTTRELL, W. Children framing childhoods and looking back. In: MOSS, J.; PINI, B. (eds.). Visual research methods in education research. Basingstoke: Palgrave MacMillan, 2016, p. 172-178.

LUTTRELL, W. Children framing childhoods: working-class kids' visions of care. Bristol: Policy Press, 2020.

LUTTRELL, W.; CHALFEN, R. Hearing voices: an introduction to dilemmas in visual research. Visual Studies, Philadelphia, v. 25, n. 3, p. 197-200, 2010. https://doi.org/10.1080/1472586X.2010.523270

MITCHELL, C. Doing visual research. London: SAGE Publications Ltd., 2011.

MOLL, L. C. et al. Funds of knowledge for teaching: using a qualitative approach to connect homes and classrooms. Theory into Practice, Columbus, v. 31, n. 2, p. 132-41, 1992. https://doi. org/10.1080/00405849209543534

ORELLANA, M. F. Space and place in an urban landscape: learning from children's views of their social world. Visual Sociology, Philadelphia, v. 14, p. 73-89, 1999. https://doi.org/10.1080/14725869908583803

PIPER, H.; FRANKHAM, J. Seeing voices and hearing pictures: image as discourse and the framing of image-based research. Discourse Studies in the Cultural Politics of Education, London, v. 28, n. 3, p. 373-387, 2007. https://doi.org/10.1080/01596300701458954

PROSSER, J.; BURKE, C. Childlike perspectives through image-based educational research. In: KNOWLES, J. G.; COLE, A. (eds.). Handbook of the arts in qualitative research: Perspectives, methodologies, examples and issues. London: SAGE Publications Ltd., 2007.

PUGH, A. Longing and belonging: parents, children, and consumer culture. Berkeley: University of California Press, 2009. 
QVORTRUP, J. et al. Childhood matters: social theory, practice, and politics. Brookfield: Avebury, 1994.

RESTLER, V. G. Re-visualizing care: teachers' invisible labor in neoliberal times. 2017. Dissertation (PhD in Philosophy) - Graduation Faculty in Urban Education, City University of New York, 2017.

RESTLER, V; LUTTRELL, W. Gaze interrupted: speaking back to stigma with visual research. In: ALDRED, P. et al (orgs.). The SAGE handbook of youth work practice. London/Thousand Oaks: SAGE Publications, 2018, p. 454-470.

ROSE, G. Visual methodologies: an introduction to the interpretation of visual materials. Los Angeles: SAGE Publications Inc., 2012.

SHALABY, C. Troublemakers: lessons in freedom from young children at school. New York: The New Press, 2017.

SHARPLES, M. et al. Children as photographers: an analysis of children's photographic behavior and intentions at three age levels. Visual Communication, London/Thousand Oaks, v. 2, n. 3, p. 303-330, 2003. https://doi.org/ 10.1177/14703572030023004

SONU, D.; BENSON, J. The quasi-human child: how normative conceptions of childhood enabled neoliberal school reform in the united states. Curriculum Inquiry, New York, v. 46, n. 3, p. 230-247, 2016. https://doi.org/10.1080/03626784.2016.1168259

TAUBMAN, P. Teaching by numbers: deconstructing the discourse of standards and accountability in education. New York: Routledge, 2009.

THOMPSON, P. (org.). Doing visual research with children and young people. London: Routledge, 2008.

THORNE, B. Re-visioning women and social change: where are the children? Gender \& Society, Newbury Park, v. 1, n. 1, p. 85-109, 1987. https://doi.org/10.1177/089124387001001005

THORNE, B. Gender play: Girls and boys in school. New Brunswick: Rutgers University Press, 1993.

TINKLER, P. A fragmented picture: Reflections on the photographic practices of young people. Visual Studies, Philadelphia, v. 23, v. 3, p. 255-266, 2008. https://doi.org/10.1080/14725860802489916

TUCK, E. Suspending damage: A letter to communities. Harvard Educational Review, Cambridge, MA, v. 79, n. 3, p. 409-428, 2009. https://doi.org/10.17763/haer.79.3.n0016675661t3n15

VINSON, K. D.; ROSS, E. W. Image and education: teaching in the face of the new disciplinarity. New York: Peter Lang, 2003.

WAKSLER, F. Studying children: phenomenological insights, Human Studies, Dordrecht, v. 9, n. 1, p. 71-82, 1986. https://doi.org/10.1007/BF00142910 
WEINER, L. Why is classroom management so vexing to urban teachers? Theory Into Practice, Columbus, v. 42, n. 4, p. 305-312, 2003. https://doi.org/10.1207/s15430421tip4204_7

YATES, L. The story they want to tell, and the visual story as evidence: young people, research authority and research purposes in the education and health domains. Visual Studies, Philadelphia, v. 25, n. 3, p. 280-291, 2010. https://doi.org/10.1080/1472586X.2010.523281 